\title{
The effects of simultaneous CS/US versus .5 seconds CS/US interval on the acquisition of a conditioned escape response
}

\author{
ROBERT L, SCHALOCK \\ MENTAL HEALTH RESEARCH INSTITUTE, FORT STEILACOOM, WASHINGTON
}

\begin{abstract}
A group of 28 naive male rats were conditioned under either a simultaneous or $.5 \mathrm{sec}$. CS/US interstimulus interval to determine the comparability of the two intervals on classical aversive conditioning. Results indicated no differences between the two interstimulus intervals.

\section{Introduetion}

Even though there is considerable evidence (Stevens, 1960) suggesting that .5 sec. is the optimum CS/US interval in classical aversive conditioning, numerous exceptions are found (Black, 1963; Boice \& Denny, 1965; Longo, Klempay, \& Bitterman, 1964; Noble \& Adams, 1963; Noble \& Harding, 1963; and Wolfle, 1932). In spite of the general acceptance of the $.5 \mathrm{sec} . \mathrm{CS} / \mathrm{US}$ interval, two studies (Prokasy, Fawcett, \& Hall, 1962 and White \& Schlosberg, 1952) have attempted to make direct comparisons between simultaneous and $.5 \mathrm{sec}$. CS/US. Both of these studies involved measuring the magnitude of GSR responses and in both .5 sec. interstimulus interval (ISI) was found superior to simultaneous CS/US. The study reportedbelow was conducted to investigate further the comparability of simultaneous versus $.5 \mathrm{sec}$. CS/US on classical aversive conditioning, utilizing a different apparatus and Ss than employed in the above two studies.
\end{abstract}

\section{Method}

The subjects (Ss) were 28, 90-day-old, naive male rats (Long-Evans strain) maintained on an adlibitum food and water diet. At the beginning of the study, the Ss were divided into two groups: (1) those conditioned on simultaneous CS/US; and (2) those conditioned on $.5 \mathrm{sec}$. CS/US.

The procedure involved giving the Ss in each respective group 20 acquisition trials on each of two consecutive days in a modified Skinner Box equipped with an electric grid floor and a revolving wheel by which the $S$ could terminate the shock. On the third consecutive day both groups were given 20 test trials with a $.5 \mathrm{sec}$. CS/US interval. The CS was a $102 \mathrm{db}$ bell placed $3 \mathrm{ft}$ from the apparatus; the US was a 100 ma shock administered through the box's electrified grid floor. The intertrial interval (ITI) was $1 \mathrm{~min}$. Response latencies were recorded for each trial and if initially the $S$ made no response within $1 \mathrm{~min}$. the shock was terminated by the experimenter and reapplied after a $1 \mathrm{~min}$. ITI.

\section{Results and Discussion}

The results indicated that there was no difference between simultaneous and $.5 \mathrm{sec}$. CS/US interval in acquiring the conditioned escape response $(F=3.27$; $\mathrm{df}=1 / 26 ; p>.05$ ) To determine, however, whether the Ss were responding to the bell which is a necessary condition in classical conditioning rather than the shock only, the data from the 20 test trials were analyzed. The results indicated that: (1) 13 of the $14 \mathrm{Ss}$ in both groups had at least two (range $=2-13$ ) avoidance responses; and (2) the groups did not differ in the number of avoidance responses during the 20 test trials $(F=1.4 ; \mathrm{df}=1 / 13 ; \mathrm{p}>.5)$. These data suggest that both groups were responding to the bell.

One can account for the disparity between this finding and that of Prokasy et al (1962) and White \& Schlosberg (1952) on the basis of an earlier postulation by Hull (1943) which stated that conditioning is most efficient when the CS/US interval is such that the receptor discharge of the CS is at its maximum frequency at the time of occurrence of the UCR. It may well be, in other words, that the time required for escaping the shock is much less than the time required to develop maximum GSR responses (Kimble, 1947 and Stevens, 1960, p. 527).

\section{References}

Black, A. H. The effects of CS-US interval on avoidance conditioning in the rat. Canad. J. Psychol., 1963, 17, 174-182.

Boice, R., \& Denny, M. R. The conditioned licking response in rats as a function of the CS-UCS interval. Psychon. Sci., 1965, 3, 93-94.

Hull, C. L. Principles of behavior: An introduction behavior theory. New York: Appleton-Century-Crofts, 1943.

Jones, Joan E. Continguity and reinforcement in relation to CS-UCS intervals in classical aversive conditioning. Psychol. Rev., 1962, $69,176-185$.

Kimble, G. A. Conditioning as a function of the time between conditioned and unconditioned stimuli. J. exp. Psychol., 1947, 37, 1-15.

Longo, N., Klempay, S. \& Bitterman, M. E. Classical appetitive conditioning in the pigeon. Psychon. Sci., 1964, 1, 19-20.

Noble, M., \& Adams, C. K. Conditioning in pigs as a function of the interval between CS and US. J. comp. physiol. Psychol., $1963,56,215-219$.

Noble, M., \& Harding, G. E. Conditioning in rhesus monkeys as a function of interval between CS and US. J. comp. physiol. Psychol., 1963, 56, 220-224.

Prokasy, W. F., Fawcett, J. T., \& Hall, J. F. Recruitment, latency, magnitude, and amplitude of the GSR as a function of interstimulus interval. J. exp. Psychol., 1962, 64, 513-518.

Stevens, S. S. (Ed.) Handbook of experimental psychology. New York: John Wiley \& Sons, Inc., 1960.

White, C. T., \& Schlosberg, H. Degree of conditioning of the GSR as a function of the period of delay. J. exp. Psychol., 1952, 43, 357-362.

Wolfe, Helen M. Conditioning as a function of the interval between the conditioned and the original stimulus. J. gen. Psychol. $1932,7,80-103$. 